\title{
OPTIMALISASI PENDATAAN PENDUDUK DI DESA PATAS MELALUI PEMANFAATAN APLIKASI SIDECI
}

\author{
I Ketut Resika Arthana ${ }^{1}$, Gede Rasben Dantes ${ }^{2}$, Kadek Eva Krishna Adnyani ${ }^{3}$ \\ 1,2, Jurusan Teknik Informatika, Fakultas Teknik dan Kejuruan Universitas Pendidikan \\ Ganesha, ${ }^{3}$ Program Studi Bahasa Jepang, Fakultas Bahasa dan Seni Universitas \\ Pendidikan Ganesha
}

email: resika@undiksha.ac.id

\begin{abstract}
ABSTRAK
Pengabdian Kepada Masyarakat (PKM) ini dilaksanakan di desa Patas, Kecamatan Gerokgak, Kabupaten Buleleng Bali dengan topik Optimalisasi Pendataan Penduduk melalui aplikasi Sistem Desa Terintegrasi(SDECI). Berdasarkan wawancara dan observasi yang dilakukan di desa Patas, desa Patas mengalami kendala dalam optimalisasi layanan pemerintahan desa terutama dalam pendataan anggota penduduk. Demografis desa yang luas dan jumlah penduduk yang banyak menjadi kendala untuk mendapatkan data yang terbaru mengenai demografi kependudukan, sehingga hal ini berdampak dalam memaksimalkan pengambilan keputusan dan pelaporan data. Di sisi lain, literasi teknologi di desa Patas sudah memadai, kantor desa sudah dilengkapi dengan komputer dan internet. Sumber daya tersebut seharusnya bisa dimanfaatkan untuk mengoptimalkan pendataan desa Patas dengan penerapan teknologi dalam akusisi data. Selain dari sumber daya teknologi, kelebihan yang dimiliki desa Patas adalah motivasi tinggi dari staf desa dalam pemanfaatan teknologi dalam penyelenggaraan pemerintah desa, hal ini terbukti dari sudah diterapkannya sistem dalam administrasi persuratan. Melalui pengabdian, tim pengabdi yang memiliki pengalaman dalam bidang penelitian dan pengembangan teknologi informasi menerapkan solusi optimalisasi pendataan pendataan penduduk. Pengabdian ini dalam bentuk penyediaan teknologi, pelatihan dan pendampingan literasi teknologi pada staff dan masyarakat desa Patas, serta pengembangan dan penerapan aplikasi Sistem Desa Cerdas Terintegrasi (SIDECI) Patas. Selain itu, pada pengabdian ini juga dilakukan pelatihan bagi perangkat desa dalam menggunakan aplikasi pendukung administrasi pemerintahaan seperti pelatihan penggunaan Aplikasi Mailmerge khususnya untuk persuratan desa, aplikasi Trello untuk manajemen penugasan dan aplikasi Google Drive dan Form untuk meningkatkan dokukemntasi dan produkfitas dalam bekerja. Berdasarkan hasil evaluasi, kegiatan ini dinilai memiliki kebermanfaatan yang tinggi terhadap peningkatan pengetahuan dan keterampilan bagi perangkat desa Patas karena pengetahuan yang disampaikan dapat diaplikasikan dalam kegiatan di kantor desa.
\end{abstract}

Kata kunci: SIDECI, Optimalisasi Pendataan, Desa Patas

\begin{abstract}
ABSTACT
The objective of this Community Service was Optimizing Population Data Collection in Patas Village via the Integrated Village System (SIDECI) program, which was carried out in Patas Village, Gerokgak District, Buleleng Regency, Bali. According to interviews and observations performed in Patas village, the local authority had difficulty in maximizing services, particularly in gathering data on population members. The village's diverse demographics and huge population make it difficult to get the most up-to-date population demographic data, which influences decision-making and data reporting. In Patas village, on the other hand, technical literacy is adequate, and the local office is equipped with computers and internet access. These resources
\end{abstract}


should be put to good use by using technology to improve data collecting in Patas village. Apart from technological resources, Patas village benefits from the strong desire of the local apparatus to utilize technology in village government administration, as evidenced by the system's adoption in correspondence administration. A group of devotees with experience in information technology research and development will apply methods to enhance village profile data collecting through community service. This service includes providing Patas village personnel and communities with guidance, training, and technical literacy support and designing and deploying the Patas Integrated Smart Village System (SIDECI) program. Additionally, this service offers training for village officials on how to use government administration support applications such as the Mailmerge application, which is especially useful for village mail, the Trello application for assignment management, and the Google Drive and Form applications to improve documentation and productivity at work. This exercise is deemed to have high advantages for developing knowledge and abilities for Patas village authorities based on the assessment results.

Keywords: SIDECI, Data Gathering, Desa Patas

\section{PENDAHULUAN}

Desa Patas merupakan desa yang berada di kecamatan Gerokgak kabupaten Buleleng Bali. Pada tahun 2019, Desa Patas memiliki jumlah penduduk 11.903 jiwa (Dinas Komunikasi, Informatika, 2021). Desa Patas memiliki 7 Dusun dan $50 \mathrm{RT}$ dengan luas desa sekitar $\pm 815 \mathrm{Ha}$. Dengan demografi penduduk yang tersebar, maka menimbulkan tantangan tersendiri dalam penyelenggaraan administrasi kependudukan terpadu terutama dalam memperoleh data penduduk untuk mendukung pengambilan keputusan dan pelaporan.

Data berkualitas sangat dibutuhkan dalam pengambilan keputusan sehingga keputusan yang diambil oleh pemerintah desa tepat sasaran terutama dalam pemberian bantuan. Data desa merupakan entitas yang sangat penting dijaga kualitiasnya karena salah satunya berkaitan dengan informasi bantuan desa yang berdampak pada kesejahteraan masyarakat. Data yang benar akan membantu target bantuan tepat sasaran. Data yang salah bisa berakibat fatal menimbulkan konflik horishontal. Seperti yang sering kita dengar di media massa, bantuan covid tidak tepat sasaran yang disebabkan sering karena database yang digunakan acuan tidak terupdate dan tidak terverifikasi. Masalah pendataan menjadi isu yang penting di desa karena masih jarang tersedia teknologi untuk membantu akusisi data serta dalam situasi Covid19 ini, diharapkan kunjungan ke rumah warga diminimalisir untuk menghindari terpapar Covid19.

Tantangan yang dihadapi di desa Patas adalah dalam mendapatkan data yang real tepat waktu karena perubahan data di tingkat individu penduduk kadangkadang tidak terdeteksi dan tidak terlaporkan. Perubahan data tersebut seperti kelahiran, kematian, perkawinan, pendatang penduduk baru dan sebagainya. Data ini sangat dibutuhkan oleh pemerintah desa karena menjadi dasar untuk penyelenggaraan informasi desa.

Saat ini staff desa Patas memiliki latar keahlian yang beragam. Sebagian besar memiliki tingkat familiar teknologi dasar sampai menengah mulai dari mengakses web, mengoperasikan aplikasi perkantoran dan membuat desain. Kemampuan yang dimiliki oleh staff desa tersebut dapat dimanfaatkan untuk meningkatkan produktifitas mereka bekerja di desa.

Saat ini pengambilan data penduduk masih dilakukan secara manual tanpa bantuan teknologi sehingga menimbulkan beberapa permasalahan yaitu dari sisi kecepatan dan validitas data. Aspek keamanan data juga menjadi isu ketika data masih didistribusikan secara manual yaitu data yang hilang. Di Desa Patas, pengambilan data secara manual mulai dari tingkat RT yang dilaporkan ke Kepala Dusun dan 
kemudian dilaporkan ke Kepala Desa. Pengambilan data manual yang melibatkan beberapa rantai komunikasi data juga berpotensi menimbulkan kekeliruan data.

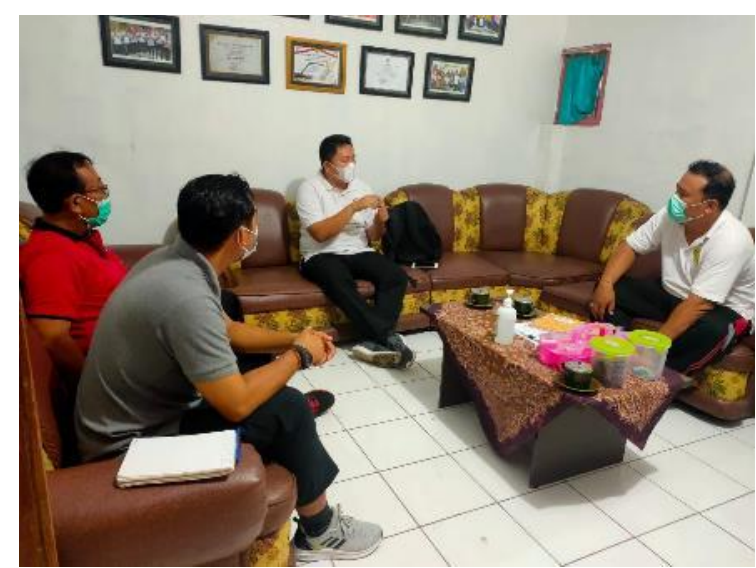

Gambar 1. Diskusi perencanaan pengabdian kepada masyarakat

Dalam wawancara yang dilakukan oleh tim pengabdi di Kantor Desa Patas pada tanggal 19 Februari 2021 (Gambar 1), kepala desa Patas I Kadek Sara Adnyana, S.Pd menyatakan keinginannya dalam optimalisasi pemanfaatan teknologi informasi sehingga bisa melayani masyarakat secara maksimal. Pemanfaatan teknologi ini mulai dari sisi pengambilan data, pemrosesan dan penyajian informasi. Kepala desa Patas juga memberikan contoh kasus jika data tidak sesuai seperti tidak tersalurkannya bantuan secara maksimal ataupun kesalahan data yang berpotensi menimbulkan kesalahan data pelaporan juga. Diharapkan, dengan kehadiran dan bantuan tim pengabdi Undiksha di desa Patas akan bisa memberikan solusi teknologi informasi untuk memaksimalkan penyelenggaraan pemerintah desa terutama dalam akuisisi data. Beliau juga menyatakan bahwa setiap desa hampir memiliki kasus sama, sehingga pengabdian dan produk yang akan dihasilkan dalam pengabdian desa Patas akan bisa diterapkan juga desa lain.
Disisi lain, dengan kemajuan teknologi saat ini terutama dalam pengembangan dan penerapan sistem informasi, berpeluang untuk diimpelementasikan teknologi untuk mempermudah dalam pendataan profil penduduk desa Patas. Teknologi terkait hal ini adalah pemrograman web dan mobile, manajemen database dan cloud computing. Tim pengabdi sendiri memiliki pengalaman dalam mengembangkan beberapa aplikasi sejenis yang mirip seperti Pendataan mahasiswa KKN berbasis aplikasi Mobile yang memanfaatkan dan menyajikan peta dalam visualisasi lokasi mahasiswa (Arthana \& Purnamawan, 2014)(Arthana et al., 2018; Krisna et al., 2019). Pada pencatatan data penduduk ini, bisa diterapkan teknologi peta juga agar dengan mudah bisa dicari lokasi tinggal masyarakat desa. Selain itu penelitian terkait penggalian potensi warisan budaya yang mengembangkan aplikasi crowdsourcing aplikasi budaya juga bisa diadopsi dalam pengabdian ini yaitu dengan mengembangkan fitur User Generated Content (UGC) dan proses validasi untuk input data. Pengalaman penelitian dan pengembangan teknologi ini sangat tepat diterapkan untuk memberikan solusi pendataan penduduk di desa Patas.

Solusi yang rencana diberikan ke masyarakat desa Patas yaitu dengan memberikan pelatihan dan pendampingan serta pengembangan/penyesuaian teknologi aplikasi sebagai media untuk pengambilan data penduduk. Dalam pengabdian ini juga akan dikembangkan teknologi yang disebut dengan Sistem Desa Cerdas Terintegrasi (SIDECI) patas untuk digunakan untuk pengambilan dan visualisasi data. SIDECI tidak dikembangkan dari awal, namun mengadopsi dari teknologi produk 


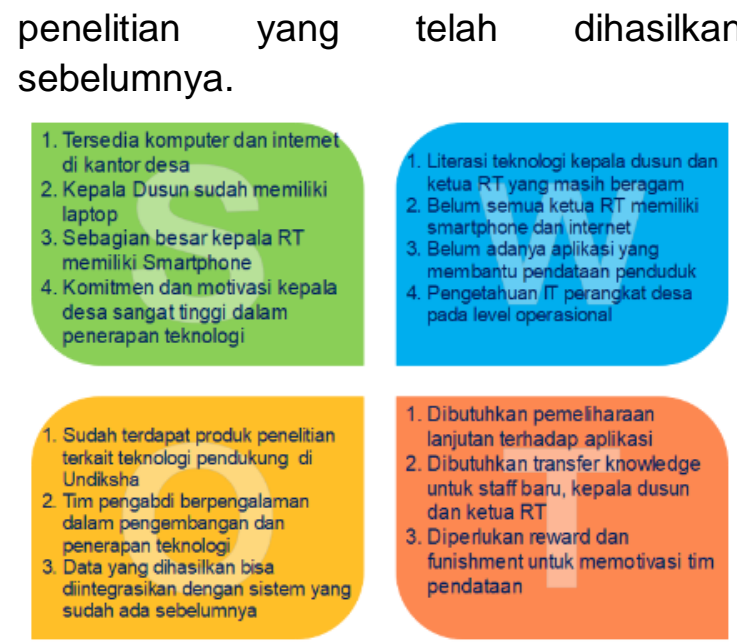

Gambar 2. Analisis SWOT

Penerapan teknologi SIDECI di desa Patas memiliki peluang tinggi berhasil berdasarkan analisa SWOT yang dilakukan. Dalam analisa SWOT tersebut ditemukan kekuatan yang dimiliki desa Patas meliputi sudah tersedianya komputer dan internet di kantor desa Patas yang nantinya digunakan untuk memonitoring, visualisasi, validasi dan verifikasi dan mengolah data lebih lanjut. Selain itu, kepemilikan teknologi laptop dan smartphone oleh kepala dusun dan ketua RT memberikan kekuatan keberhasilan program karena peralatan dasar sudah dimiliki oleh petugas pencatatan kependudukan. Hal yang terpenting dari kekuatan keberhasilan PKM ini adalah komitmen dann motivasi yang tinggi dari kepala desa dalam pelaksanaan.

Adapun solusi yang diberikan pada P2M ini adalah solusi dari kelemahan (Weakness) dari SWOT. Kelemahan yang saat ini terjadi secara internal adalah literasi teknologi kepala dusun dan ketua RT yang masih beragam. Dalam PKM ini akan diberikan pelatihan dan pendampingan kepada kepala dusun dan ketua RT dalam penggunaan teknologi SIDECI. Selain itu, belum semua kepala RT memiliki Smartphone juga diberikan solusi dalam PKM ini berupa fitur aplikasi SIDECI yang mengijinkan input data dari level kepala dusun. Sehingga jika ketua
RT tidak bisa input data, maka kepala dusun bisa membantu input data. Kelemahan lain adalah belum adanya aplikasi yang membantu pendataan penduduk adan pengetahuan IT perangkat desa berada pada level manual diberikan solusi dalam bentuk penyediaan teknologi berupa aplikasi SIDECI yang diadopsi dari produk penelitian tim pengabdi sebelumnya.

\section{METODE}

Berdasarkkan dari permasalahan yang dihadapi desa Patas, maka kerangka pemecahan masalahnya terdiri dari Identifikasi Permasalahan, Penentuan Solusi, Pengembangan Tools Pendukung, Pelatihan dan Pendampingan serta Evaluasi.

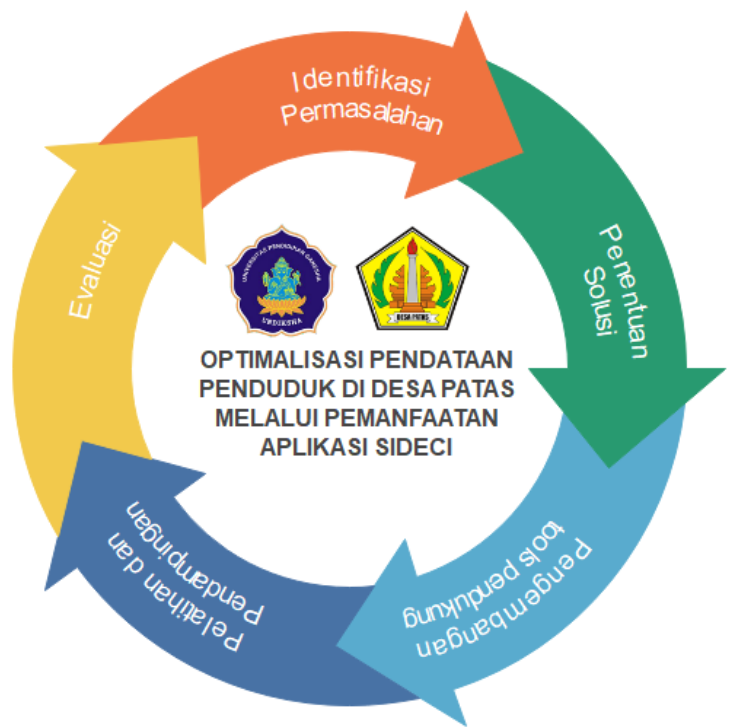

Gambar 3. Metode Pemecahan Masalah

\section{a. Identifikasi Permasalahan}

1. Kebutuhan data valid terutama untuk pendataan bantuan dan pelaporan sangat urgent

2. Kendala dalam mendapatkan data penduduk yang berkualitas (akurat, tepat waktu, relevan)

3. Lokasi tinggal penduduk yang tersebar

4. Sudah tersedia teknologi pendukung namun belum optimal

5. Perlu peningkatan literasi staff untuk pemanfaatan dan pengembangan teknologi 
6. Perlu mekanisme pendataan yang aman dari bahaya Covid19

\section{b. Penentuan Solusi}

1. Implementasi hasil penelitian tim pengabdi sebagai solusi teknologi

2. Penerapan teknologi aplikasi SIDECI (Sistem Desa Cerdas Terintegrasi)

3.Pembinaan, pelatihan dan pendampingan pemanfaatan teknologi untuk pendataan penduduk

\section{Pengembangan aplikasi SIDECI}

Pada tahapan ini, dikembangkan aplikasi SIDECI berbasis web yang memiliki kebutuhan fungsional untuk pendataan penduduk di Desa Patas. Jumlah Adapun actor dalam system ini terdiri dari administrator, operator desa, ketua RT dan masyarakat umum. Dalam pelatihan P2M ini diikuti oleh 23 orang staff desa Patas

\section{d. Pelatihan dan Pendampingan}

Pada tahapan ini dilakukan pelatihan dan pendampingan bagi perangkat desa dalam menggunakan aplikasi SIDECI. Selain aplikasi SIDECI, pada pelatihan ini juga dikenalkan beberapa aplikasi yaitu Excel fitur Mail Merge, Trello untuk manajemen penugasan dan Google Drive dan Form untuk meningkatkan produktifitas.

\section{e. Evaluasi}

Evaluasi dilakukan untuk mendapatkan informasi mengenai tingkat keberhasilan pengabdian, serta kendalakendala yang dihadapi. Adapun indicator keberhasilan kegiatan ini meliputi kebermanfaatan program dan keberlanjutan implementasi

\section{HASIL DAN PEMBAHASAN}

\section{A. Pengembangan Produk}

Sebelum pelaksanaan pelaksanaan pelatihan, tim pengabdi mengembangkan aplikasi SIDECI sesuai dengan daftar kebutuhan fungsional desa Patas. Adapun daftar kebutuhan fungsional aplikasi SIDECI meliputi :
1. Manajemen data ketua RT yang bertugas mengelola data penduduk sesuai masing-masing RT

2. Manajemen data penduduk

3. Manajemen pengguna aplikasi

4. Eksport data sesuai Buku Induk

5. Dashboard yang menampilkan data penduduk desa Patas

Adapun pengguna dari aplikasi ini terdiri dari :

1. Masyarakat:Melihat dashboad penduduk desa

2. Operator:Manajemen data penduduk desa Patas

3. Ketua RT:Manajemen data berdasarkan lingkup RT

4. Administrator :Memiliki semua hak akses pada sistem SIDECI.

Adapun tampilan aplikasi SIDECI adalah sebagai berikut :

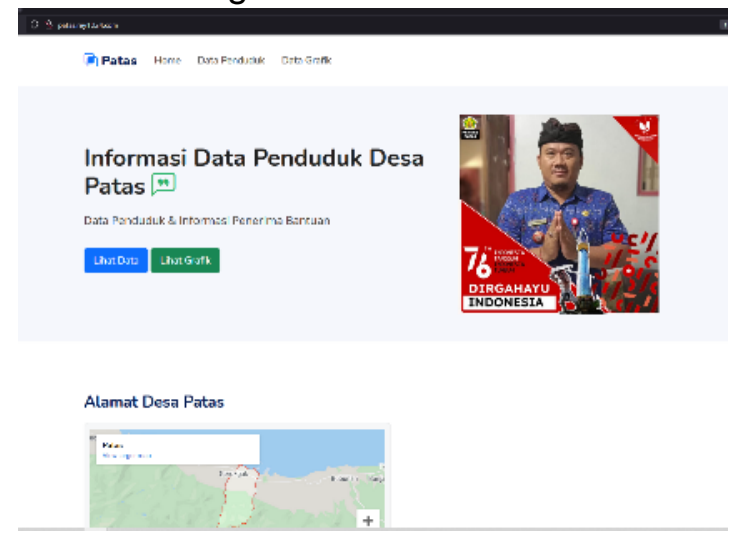

Gambar 4. Tampilan Utama Aplikasi SIDECI

Pada menu Data Penduduk, masyarakat bisa melihat data penduduk yang ada di desa Patas termasuk data dampak Covid dan status Bantuan. (Data yang ditampilkan adalah data Dummy)

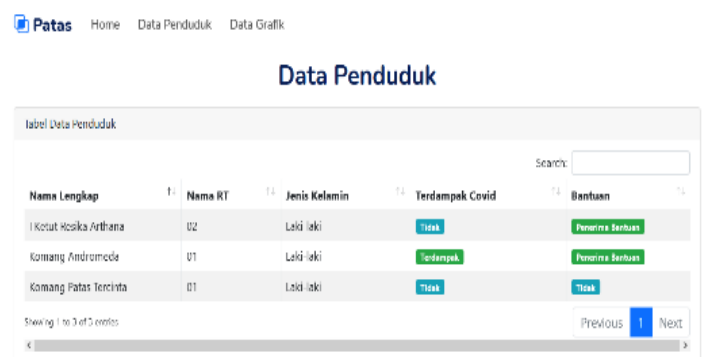

Gambar 5. Data Penduduk 
Pada menu Data Grafik (Gambar 5), tampil dashboard data penduduk desa Patas. Dashboard ini menampilkan grafik sesuai data yang sudah terekam. Dashboard ini bisa diakses oleh seluruh masyarakat.

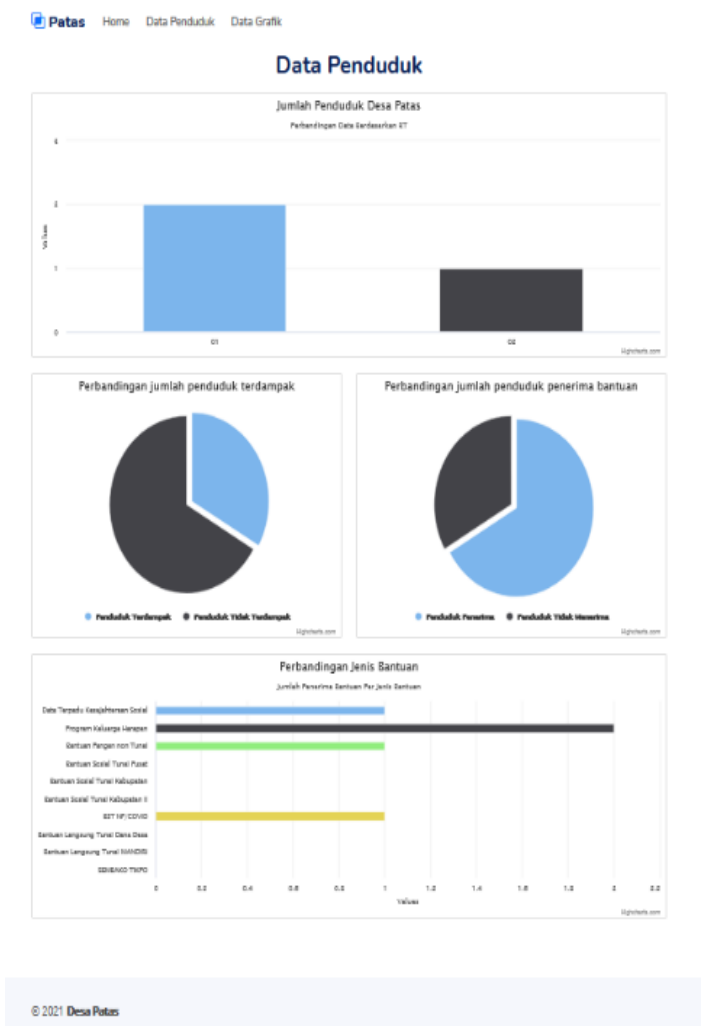

Gambar 6. Dashboard SIDECI

Masyarakat desa dan kepala desa bisa melihat grafik kondisi penduduk desa terkini melalui menu Dashboard aplikasi SIDECI seperti yang ditampilkan pada Gambar 6.

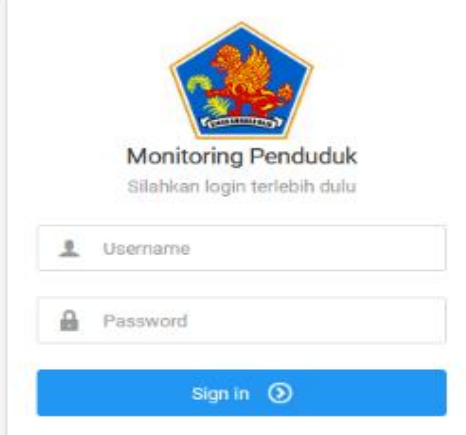

Gambar 7. Login

Setiap pengguna memiliki hak akses masing-masing dengan cara login terlebih dahulu (Gambar 7). Admin bisa mengelola data RT dan data seluruh Penduduk Desa Patas. Sedangkan Ketua RT bisa mengelola data penduduk di daerahnya.

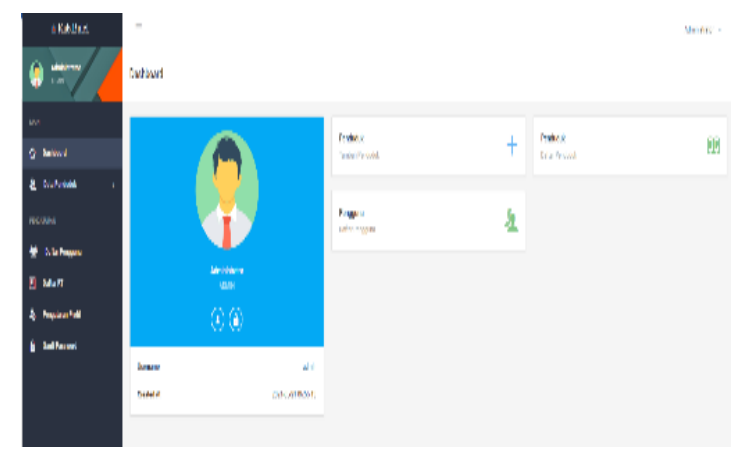

Gambar 8. Dashboard Administrator

Setelah administrator login, admin dapat mengelola data RT, penduduk, export data dan pengaturan lainnya. Administrator merupakan pemegang hak akses tertinggi dalam system, seperti yang terlihat pada Gambar 8 
Jurnal Widya Laksana, Vol.11, No.1, Januari 2022

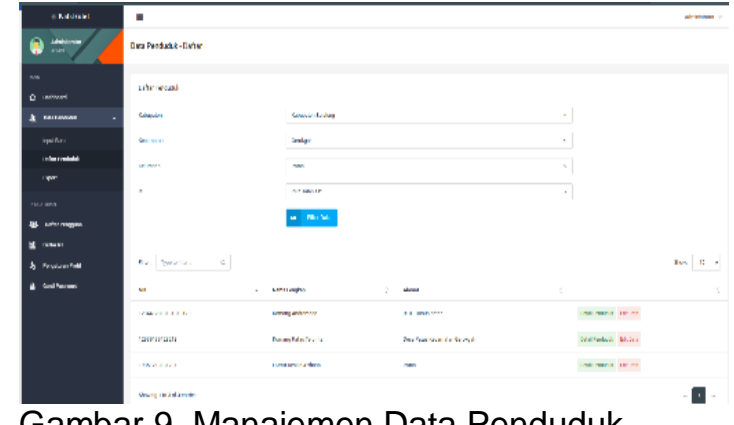

Gambar 9. Manajemen Data Penduduk

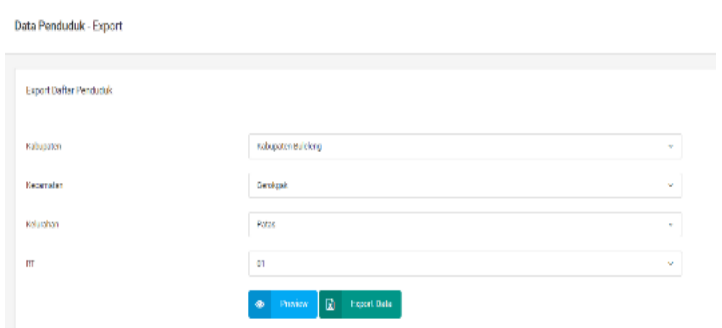

Gambar 10. Export Data

Pada menu Export, operator desa bisa mengunduh file excel yang berisi data penduduk sesuai format data buku Induk (Gambar 10).

\section{B. Pelatihan}

Pelatihan dan pendampingan dilakukan secara daring karena kondisi pandemi COVID19 dan saat ini masih PKKM Level 4. Komunikasi dengan pihak desa Patas dilakukan sejak proposal ini disetujui meliputi diskusi pemanfaatan sistem informasi desa, konsultasi, pembelian sistem, teknologi tepat guna dan sebagainya.

Puncak pelaksanaan pelatihan dan pendampingan P2M desa Patas dilakukan pada tanggal 9 Agustus 2021 secara daring. Kegiatan ini diikuti oleh tim pelaksana P2M beserta 4 mahasiswa serta pihak desa Patas.

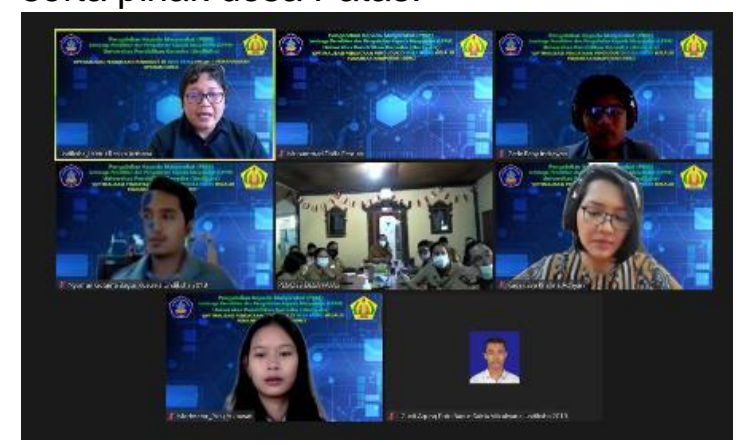

Gambar 11 Peserta Kegiatan P2M

Adapun kegiatannya adalah sebagai berikut.

Tabel 1. Kegiatan P2M di Desa Patas

\begin{tabular}{|c|c|}
\hline Waktu & Acara \\
\hline $09.00-09.30$ & $\begin{array}{l}\text { - Pembukaan } \\
\text { - Laporan Ketua Pelaksana } \\
\text { - Sambutan dan pembukaan oleh Kepala Desa Patas } \\
\text { - Foto bersama }\end{array}$ \\
\hline $09.30-10.00$ & $\begin{array}{l}\text { - Aplikasi Sistem Desa Cerdas Terintegrasi (Untuk } \\
\text { pendataan penduduk desa Patas) }\end{array}$ \\
\hline $10.00-10.15$ & Diskusi \\
\hline $10.15-11.00$ & $\begin{array}{l}\text { Aplikasi Pendukung Pemerintahan Desa } \\
\text { - Excel (Mailmerge) } \\
\text { - Pembagian Tugas dan Penjadwalan } \\
\text { (Trello) } \\
\text { - Google Suite (Drive, Form) }\end{array}$ \\
\hline 11.00-Selesai & Diskusi \\
\hline
\end{tabular}


Laporan Ketua Pelaksana dilakukan oleh ketua Pelaksana P2M yaitu I Ketut Resika Arthana, S.T., M.Kom. Dalam laporannya, ketua pelaksana menyampaikan latar belakang kegiatan, tujuan kegiatan dan jenis pelatihan dan pendampingan yang dilakukan untuk desa Patas. Dalam kesempatan ini, ketua pelaksana kegiatan juga menyampaikan solusi-solusi yang bisa diterapkan di desa Patas untuk memperlancar kegiatan administrasi pemerintahan desa Patas.

Setelah laporan ketua pelaksana, acara dilanjutkan dengan smbutan dan pembukaan oleh kepala desa Patas. Dalam Sambutannya, Kepala desa Patas (I Kadek Sara Adnyana, S.Pd) menyampaikan beberapa kendala di desa Patas terkait teknologi informasi. Selain itu, beliau juga mengucapkan terima kasih kepada Undiksha karena telah menyelenggarakan P2M ini.

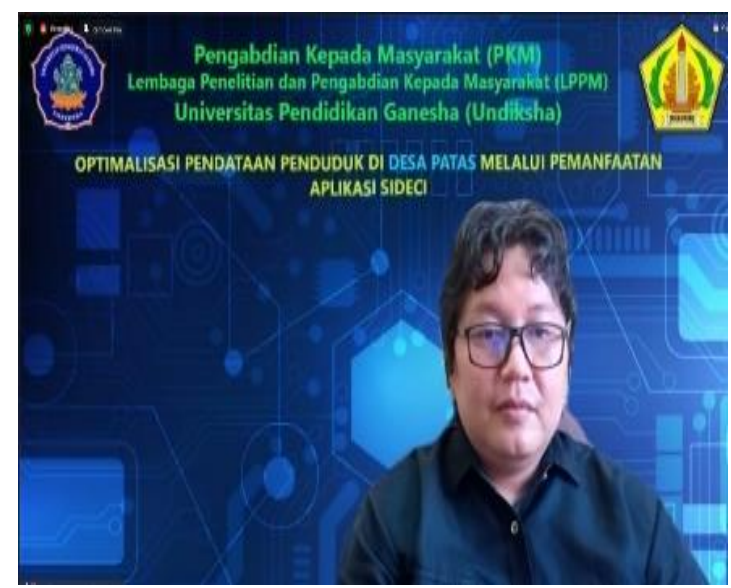

Gambar 12. Laporan Ketua Pelaksana

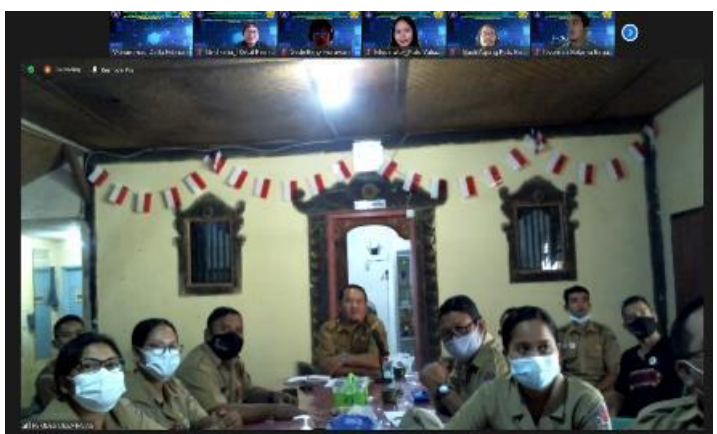

Gambar 13. Sambutan Kepala Desa Patas

Acara kemudian dilanjutkan dengan pemaparan materi terkait teknologi yang bisa dimanfaatkan di desa Patas untuk pendataan penduduk, yaitu aplikasi SIDECI. Aplikasi ini didemokan langsung oleh ketua pelaksana pengabdian. Setelah sesi ini, dilakukan diskusi terkait teknis implementasi dan pengelolaan data.

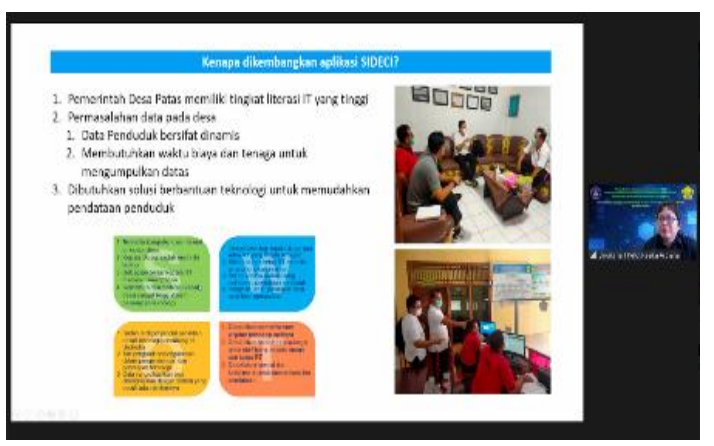

Gambar 14. Materi SIDECI

Acara kemudian dilanjutkan dengan pemaparan materi pendukung pemerintahan desa Patas (Gambar 15).

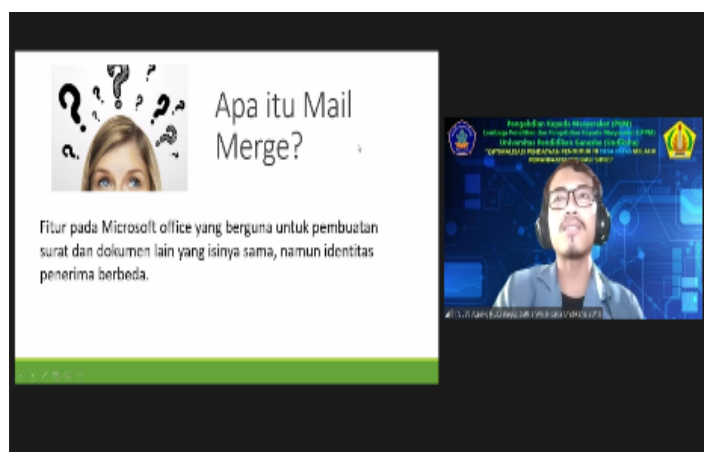

Gambar 15. Materi Mailmerge

Materi pengenalan MailMerge pada Excel disampaikan oleh I Gusti Agung Putu Bagus Satria Wicaksana. Mailmerge sangat dibutuhkan oleh pemerintah desa Patas untuk mempermudah pembuatan surat yang banyak dimana formatnya sama, seperti surat keterangan miskin, dan sebagainya. 


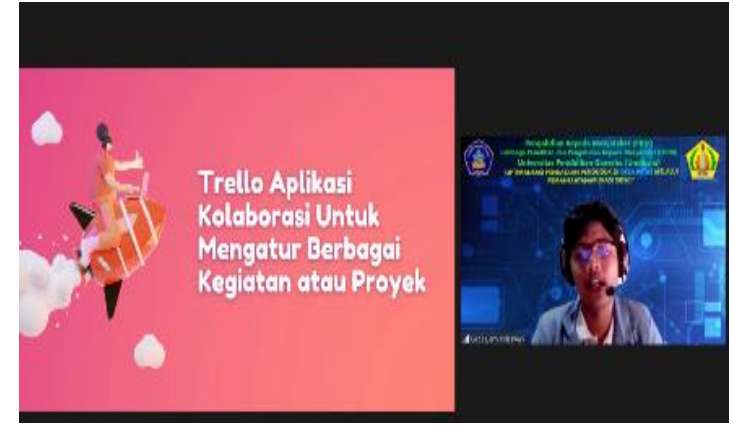

Gambar 16. Materi Trello

Materi selanjutnya yaitu terkait bagaimana manejemen penugasan di kantor (Gambar ). Tugas biasanya sangat banyak, untuk itu dibutuhkan tools yang membantu mendistribusikan tugas dan memantau progress tugas tersebut. Tools yang digunakan adala Trello. Materi ini disampaikan oleh Gede Beny Indrawan dari program studi IImu Komputer.

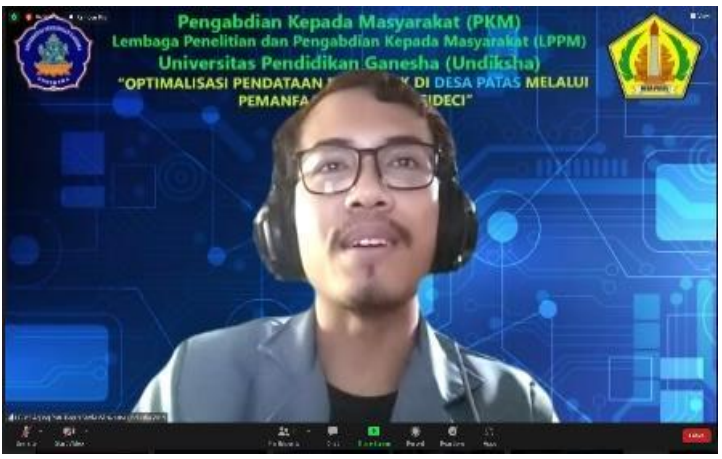

Gambar 17. Materi Google Suite

Selanjutnya acara dilanjutkan dengan penyampaian materi dari Nyoman Gotama Bagus Kusuma terkait pemanfaatan Google Drive dan Form. Google Drive sangat penting dimanfaatkan oleh pemerintah desa untuk menyimpan data sehingga mereka bisa bekerja darimana saja dan kapan saja. Sedangkan Google Form sangat penting mereka ketahui untuk memudahkan melakukan survey dan pengambilan data di masyarakat.

\section{Evaluasi}

Berdasarkan kuisioner yang disebarkan, staff desa Patas 100\% menyatakan akan melanjutkan implementasi SIDECI untuk pendataan penduduk .

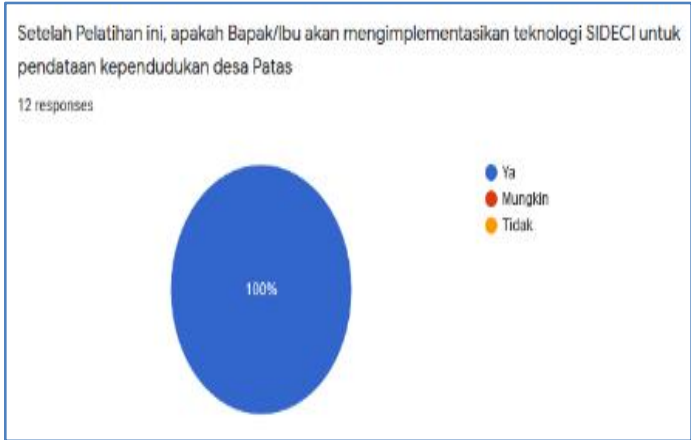

Gambar 18. Kesediaan Implementasi

Selain itu, 25\% staff desa Patas menyatakan membuthkan pendampingan lagi setelah pelatihan ini, untuk itu diperlukan pendampingan lanjutan dalam pelaksanaan PKM ini.

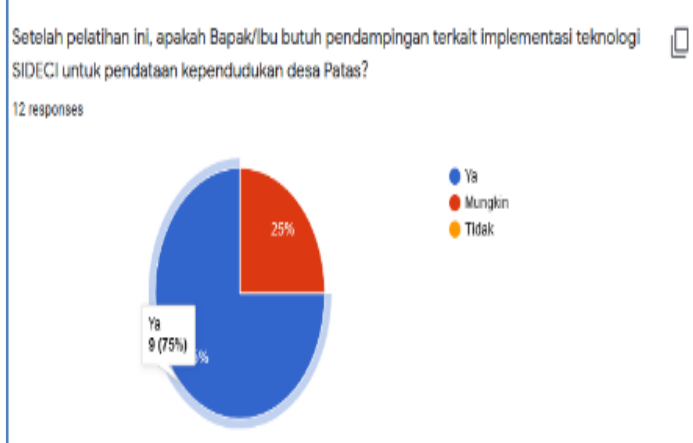

Gambar 11. Pendampingan

Sedangkan kedepannya diperlukan pelatihan lanjutan seperti pemutahiran data penduduk, penggunaan rumus Excel serta system pengelolaan keuangan desa berbasis teknologi informasi untuk menunjang penyelenggaraan pemerintah desa.

\section{KESIMPULAN}

PKM yang dilaksanakan di desa Patas yang mengambil topik optimalisasi pendataan penduduk dengan aplikasi SIDECI sudah dilaksanakan dan dibutuhkan pendampingan lebih lanjut. PKM ini dilaksanakan dengan tujuan memberikan solusi teknologi terkait pendataan penduduk. Selain itu pada PKM ini juga diberikan pelatihan terkait teknologi tepat guna untuk menunjang pemerintahan desa Patas. 
Pada PKM ini dikembangkan aplikasi SIDECI berbasis web yang digunakan oleh ketua RT untuk manajemen data penduduk sesuai dengan daerah RT nya. Selain itu pada aplikasi SIDECI juga bisa dimanfaatkan oleh staff desa untuk melihat data penduduk secara keseluruhan. SIDECI menyajikan data dalam bentuk dashboard untuk memudahkan kepala desa dan masyarakat umum untuk melihat perkembangan data desa.

Berdasarkan hasil evaluasi, kegiatan ini dinilai memiliki kebermanfaatan yang tinggi terhadap peningkatan pengetahuan dan keterampilan bagi perangkat desa Patas.

\section{DAFTAR PUSTAKA}

Arthana, i. K. R., pradnyana, g. A., \& pradnyana, i. M. A. (2018). Prototype aplikasi mobile preservasi warisan budaya indonesia berbasis crowdsourcing. Jst (jurnal sains dan teknologi), $\quad 7(1)$,

59.

Https://doi.org/10.23887/jst-

undiksha.v6i2.11924
Arthana, i. K. R., \& purnamawan, i. K. (2014). Pengembangan sistem informasi geografis kuliah kerja nyata (kkn) undiksha berbasis teknologi mobile dan location based service. Academia.

Https://www.academia.edu/14851591 /pengembangan_sistem_informasi_g eografis_kuliah_kerja_nyata_kkn_und iksha_berbasis_teknologi_mobile_da n_location_based_service

Dinas komunikasi, informatika, p. Dan s. B. (2021). Penerapan aplikasi e-data menuju satu data buleleng: jumlah penduduk per jenis kelamin. Http://permata.bulelengkab.go.id/ddata/kependudukan/jumlahpenduduk-per-jeniskelamin?tahun=2019

Krisna, k., arthana, i. K. R., \& pradnyana, g. A. (2019). Pengujian usability pada prototype aplikasiwadaya dengan metode usability testing mengadopsi standar iso 9241:11. Ultimatics: jurnal teknik informatika, 11(1). Https://doi.org/https://doi.org/10.3193 7/ti.v11i1.1240 